\title{
Sequence analysis of the internal transcribed spacer 2 (ITS2) region of rDNA for identifying Trichogramma species and evaluating genetic diversity
}

\author{
J. B. V. Viana ${ }^{a}$ (D), R. B. Querino ${ }^{b}$ (D) L. C. B. Carvalho ${ }^{a}$ (D) and P. S. C. Lima ${ }^{b}$ \\ anniversidade Federal do Piauí - UFPI, Centro de Ciências Agrárias - CCA, Programa de Pós-graduação em Genética e \\ Melhoramento, Teresina, PI, Brasil \\ ${ }^{\mathrm{b}}$ Embrapa Meio Norte, Teresina, PI, Brasil \\ *e-mail: paulo.costa-lima@embrapa.br
}

Received: December 23, 2019 - Accepted: May 6, 2020 - Distributed: November 30, 2021

(With 1 figure)

\begin{abstract}
Species of Trichogramma Westwood, 1833 (Hymenoptera: Trichogrammtidae) are frequently used as biological control agents against Lepidoptera, but practical application of these egg endoparasitoids are complicated because of their complex taxonomy. This study aimed to compare sequences of internal transcribed spacer regions of ribosomal DNA (ITS2-rDNA) of Trichogramma accessions with those deposited in GenBank in order to access the reliability of the ITS2 as a barcode for discriminating species and evaluating the genetic diversity. ITS2-rDNA sequences obtained from seventeen specimens of Trichogramma confirmed previous identifications based on morphological characteristics. Multiple sequence alignment revealed the existence of highly conserved regions in ITS2 sequences while the neighbourjoining dendrogram indicated that the specimens formed three clusters comprising T. manicobai and T. marandobai (group I), T. galloi (group II) and T. pretiosum (group III). The ITS2 marker was shown to be a powerful DNA barcode for discriminating Trichogramma species and could be used to complement the morphological approach.
\end{abstract}

Keywords: Lepidoptera, Trichogramma spp., egg parasitoids, nucleotide polymorphisms, genetic similarity.

\section{Análise de sequência do rDNA da região espaçadora do transcrito interno 2 (ITS2) para identificar espécies de Trichogramma e avaliar a diversidade genética}

\begin{abstract}
Resumo
Espécies de Trichogramma Westwood, 1833 (Hymenoptera: Trichogrammatidae) são freqüentemente usadas como agentes de controle biológico contra Lepidoptera, esses endoparasitóides de ovos apresentam taxonomia complexa, o que dificulta sua aplicação prática. Este estudo teve como objetivo comparar seqüências de regiões espaçadoras internas transcritas de DNA ribossômico (ITS2-rDNA) de acessos de Trichogramma com aquelas depositadas no GenBank, a fim de avaliar a confiabilidade do ITS2 barcode para discriminar espécies e avaliar a diversidade genética. As seqüências de ITS2-rDNA obtidas de dezessete espécimes de Trichogramma confirmaram identidades anteriores com base em características morfológicas. O alinhamento de múltiplas sequências revelou a existência de regiões altamente conservadas nas sequências ITS2, enquanto o dendrograma indicou que os espécimes formavam três grupos compreendendo T. manicobai e T. marandobai (grupo I), T. galloi (grupo II) e T. pretiosum (grupo III). O marcador ITS2 mostrou ser um poderoso DNA barcode para discriminar espécies de Trichogramma podendo ser usado como complemento da abordagem morfológica.
\end{abstract}

Palavras-chave: Lepidoptera, Trichogramma spp., parasitóides de ovos, polimorfismo de nucleotídeos, similaridade genética.

\section{Introduction}

Trichogramma Westwood, 1833 (Hymenoptera: Trichogrammatidae) is a genus of minute parasitic wasps comprising 210 registered species worldwide (Pinto, 2006). According to Zucchi et al. (2010), 41 species of Trichogramma have been reported in South America and 26 of these are found in Brazil, the country considered to harbor the highest number of known species. All Trichogramma species are endoparasitoids of the eggs of Lepidoptera pests and, for this reason, they are frequently used as biological control agents in integrated pest management (IPM) programs. 
The success of a biological control strategy employing parasitic wasps depends to a large extent on the correct identification of the Trichogramma species. Such identifications were originally based exclusively on the external morphology of adult specimens but, following the studies of Nagarkatti and Nagaraja (1977), another alternative take into consideration the morphological characteristics of male genitalia (Querino et al., 2010). However, despite the substantial practical applications of Trichogramma parasitoids, studies of members of this genus are complicated by their complex taxonomy, minute size, the occurrence of intraspecific variations and the appearance of cryptic species (Pinto et al., 1989; Querino and Zucchi, 2002; Querino et al., 2002).

Along with the correct identification of the parasitoid species, a successful control program relies on information regarding the genetic diversity of Trichogramma populations. Additionally, it is important to obtain a knowledge of local diversity in order to conserve a reservoir of native parasitoids since it is not possible to predict which pests are likely to emerge in the future (La Salle and Gauld, 1993). Moreover, future environmental modifications may give rise to intraspecific variations that could alter the role of parasitoids in the regulation of other insect populations. In consideration of the above, studies using innovative approaches are needed to advance our knowledge of the taxonomy and genetic diversity of economically important species of Trichogramma.

Molecular marker techniques have contributed significantly to our understanding of population genetics, taxonomy, conservation biology and genetic diversity among natural insect populations (Van Oosterhout et al., 2004). In particular, sequencing of the internal transcribed spacer (ITS) region of ribosomal DNA (rDNA) has been particularly useful in providing a barcode for elucidating intraspecific variations and species differentiation in various groups of organisms including insects. Moreover, ITS1 and ITS2 sequences allow the phylogenetic reconstruction of relationships between closely related species and reveal population differentiation and structure (Vieira et al., 2014, 2015).

The aim of the present study was to compare ITS2rDNA sequences of Trichogramma specimens from different origins with those deposited in GenBank in order to assess the reliability of ITS2 as a DNA barcode for discriminating species and evaluating genetic diversity among different populations.

\section{Material and Methods}

\subsection{Sampling}

Seventeen samples of Trichogramma originating from eight different pest hosts and seven different plant species were collected in the Brazilian states of Alagoas, Pará and Piauí (Table 1). The samples had been previously identified as members of the species T. marandobai Brun, Moraes \& Soares, 1984, T. pretiosum Riley, 1879, T. galloi Zucchi, 1988 or T. manicobai Brun, Moraes \& Soares, 1984, based on the morphology of the genitalia, antennae and wings of adult males according to the illustrated key of Querino and Zucchi (2005, 2012). Voucher specimens were deposited in the Insect Collection at Embrapa Meio-Norte (Teresina, PI, Brazil).

\subsection{DNA extraction and Polymerase Chain Reaction $(P C R)$}

Genomic DNA was extracted by transferring a single Trichogramma specimen to a $0.2 \mathrm{~mL}$ microtubes containing $80 \mu \mathrm{L}$ of $5 \%$ Chelex ${ }^{\circledR} 100$ (Bio-Rad, Hercules, CA, USA) and $8 \mu \mathrm{L}$ of $20 \mathrm{mg} \mathrm{mL}^{-1}$ of proteinase $\mathrm{K}$ solution. The mixture was incubated at $95{ }^{\circ} \mathrm{C}$ for $20 \mathrm{~min}$ in a thermocycler, submitted to gentle shaking, centrifuged at $8603 \mathrm{~g}$ for $45 \mathrm{~s}$ and the supernatant transferred to a new tube and stored at $-20{ }^{\circ} \mathrm{C}$. A NanoDrop ${ }^{\mathrm{TM}}$ (Thermo Fisher Scientific, Waltham, MA, USA) UV-Vis spectrophotometer was used to quantify and assess the purity of extracted DNA.

The ITS2 region of ribosomal DNA was amplified as described by Stouthamer et al. (1999) using the primers 5'-TGTGAACTGCAGGACACATG-3' (forward) and 5' -GTCTTGCCTGCTCTGAG 3' (reverse). The PCR reaction mixture contained $2.5 \mu \mathrm{L}$ of $10 \mathrm{X}$ Taq buffer (containing $25 \mathrm{mM} \mathrm{MgCl}_{2}$ ), $3.75 \mu \mathrm{L}$ of $25 \mathrm{mM} \mathrm{MgCl}_{2}$, $2 \mu \mathrm{L}$ of $10 \mathrm{mM}$ dNTPs, $0.25 \mu \mathrm{L}$ of Q-solution (Qiagen, Hilden, Germany), $0.5 \mu \mathrm{L}$ of forward primer, $0.5 \mu \mathrm{L}$ of reverse primer, $0.13 \mu \mathrm{L}$ of Taq DNA polymerase $\left(5 \mathrm{U}_{\mu} \mathrm{L}^{-1}\right.$; Invitrogen, Life Technologies do Brasil, São Paulo, SP, Brazil), $6 \mu \mathrm{L}$ of DNA template (variable concentration) and $9.37 \mu \mathrm{L}$ of ultrapure distilled water to a final volume of $25 \mu \mathrm{L}$. Amplification reactions were carried out in a Veriti 96 Well Thermal Cycler (Applied Biosystems, Foster City, CA, USA) under the following conditions: initial denaturation for $3 \mathrm{~min}$ at $94{ }^{\circ} \mathrm{C}$, followed by 33 cycles each comprising denaturation for $40 \mathrm{~s}$ at $94{ }^{\circ} \mathrm{C}$, annealing for $45 \mathrm{~s}$ at $55^{\circ} \mathrm{C}$, extension for $45 \mathrm{~s}$ at $72{ }^{\circ} \mathrm{C}$, and a final extension for $5 \mathrm{~min}$ at $72^{\circ} \mathrm{C}$. The resulting PCR products were separated by electrophoresis on $1.5 \%$ agarose gel for $90 \mathrm{~min}$ at $90 \mathrm{~V}$, stained with 1:1000 GelRed ${ }^{\mathrm{TM}}$ (Biotium, Hayward, CA, USA), visualized under a UV transilluminator and subsequently photographed. Sizes of the ITS2 amplicons were estimated by comparison with a 1 kb DNA ladder (Invitrogen). In order to obtain DNA of a quality suitable for sequencing, PCR products were purified using Invisorb ${ }^{\circledR}$ Fragment CleanUp (Stratec Biomedical, Birkenfeld, Germany) according to the manufacturer's recommendations.

\subsection{DNA sequencing and analysis}

ITS2 amplicons were sequenced by ACTGene Análises Moleculares (Centro de Biotecnologia, Universidade Federal do Rio Grande do Sul, Porto Alegre, RS) using a model AB 3500 Genetic Analyzer (Thermo Fisher Scientific) equipped with $50 \mathrm{~cm}$ capillaries and POP-7 ${ }^{\mathrm{TM}}$ polymer (Thermo Fisher Scientific). DNA templates (30-40 $\mathrm{ng}$ ) were labeled using a reaction solution containing $2.5 \mathrm{pmol}$ of each primer and $0.5 \mathrm{~mL}$ 
Table 1. Origin of the accessions of Trichogramma.

\begin{tabular}{|c|c|c|c|}
\hline Species/specimen & Lepidopteran pest (host) & Plant & Location \\
\hline \multicolumn{4}{|l|}{ T.pretiosum } \\
\hline T.pret01 & $\begin{array}{l}\text { Heraclides thoas Rothschild \& Jordan, } \\
1906 \text { (Papilionidae) }\end{array}$ & pepper & Teresina, PI \\
\hline T.pret02 & H. thoas & pepper & Teresina, PI \\
\hline T.pret03 & H. thoas & pepper & Teresina, PI \\
\hline T.pret04 & $\begin{array}{l}\text { Agraulis vanillae Linnaeus, } 1758 \\
\text { (Nymphalidae) }\end{array}$ & passion fruit & Teresina, PI \\
\hline T.pret05 & A. vanillae & passion fruit & Teresina, PI \\
\hline T.pret06 & A. vanillae & passion fruit & Teresina, PI \\
\hline T.pret09 & $\begin{array}{c}\text { Alabama argillacea Hübner, } 1818 \\
\text { (Noctuidae) }\end{array}$ & cotton & Teresina, PI \\
\hline T.pret10 & A. argillacea & cotton & Teresina, PI \\
\hline T.pret11 & $\begin{array}{c}\text { Spodoptera frugiperda Smith, } 1797 \\
\text { (Noctuidae) }\end{array}$ & cotton & Teresina, PI \\
\hline \multicolumn{4}{|l|}{ T. galloi } \\
\hline T.gal01 & $\begin{array}{c}\text { Diatraea saccharalis Fabricius, } 1794 \\
\text { (Crambidae) }\end{array}$ & rice & Teresina, PI \\
\hline T.gal02 & D. saccharalis & rice & Teresina, PI \\
\hline T.gal03 & D. saccharalis & rice & Teresina, PI \\
\hline \multicolumn{4}{|l|}{ T. manicobai } \\
\hline T.man 01 & $\begin{array}{l}\text { Erinnyis ello Linnaeus, } 1758 \\
\text { (Sphingidae) }\end{array}$ & cassava & Rio Largo, AL \\
\hline \multicolumn{4}{|l|}{ T. marandobai } \\
\hline T.mar 01 & E. ello & cassava & Rio Largo, AL \\
\hline T.mar 02 & E. ello & cassava & Rio Largo, AL \\
\hline T.mar 03 & E. ello & cassava & Belém, PA \\
\hline \multicolumn{4}{|l|}{ Unidentified $^{A}$} \\
\hline T.sp01 & $\begin{array}{c}\text { Chrysodeixis includens Walker, } 1858 \\
\text { (Noctuidae) }\end{array}$ & cowpea & São João, PI \\
\hline
\end{tabular}

of the BigDye ${ }^{\mathrm{TM}}$ Terminator v3.1 Cycle Sequencing reagent (Thermo Fisher Scientific) in a final volume of $10 \mathrm{~mL}$. Labeling reactions were performed using a XP Cycler (Bioer, Tokyo, Japan) under the following conditions: initial denaturation for $3 \mathrm{~min}$ at $96{ }^{\circ} \mathrm{C}$, followed by 25 cycles each comprising $10 \mathrm{~s}$ at $96{ }^{\circ} \mathrm{C}, 5 \mathrm{~s}$ at $55^{\circ} \mathrm{C}$ and 4 min at $60{ }^{\circ} \mathrm{C}$, and finally held at $4{ }^{\circ} \mathrm{C}$ until required for purification. Labeled samples were purified by precipitation with $75 \%$ isopropanol and washing the sediments with $60 \%$ ethanol. The precipitates were diluted in $10 \mathrm{~mL}$ of $\mathrm{Hi}-\mathrm{Di}^{\mathrm{TM}}$ formamide (Thermo Fisher Scientific), denatured at $95{ }^{\circ} \mathrm{C}$ for $5 \mathrm{~min}$, cooled on ice for $5 \mathrm{~min}$ and injected into the automatic sequencer. Data were collected using ABI PRISM 310 Data Collection Software v2.0 (Applied Biosystems).

Similarities between the obtained ITS2 sequences and those recorded in GenBank (NCBI - National Center was Biotechnology Information) were explored using the Basic
Local Alignment Search Tool BLASTN (Altschul et al., 1990; Johnson et al., 2008). Trichogramma species were identified from sequence similarity scores and percentages of similarity. For each sample, paired forward and reverse reads were combined into contigs. Clustal W/Clustal Omega software, with gap opening penalty set at -9 and extension penalty set at -3 , were employed to perform multiple sequence alignments and to generate the phylogenetic tree. Sites that presented around $80 \%$ similarities were considered conserved.

Cluster analysis was performed using the maximum composite likelihood and the dendrogram created using the neighbor-joining agglomerative clustering method. Bootstrapping with 1000 iterations of the data set was employed to assess confidence in the topologies obtained. All analyzes were performed using the Molecular Evolutionary Genetic Analysis (MEGA) version 10.1.7 software (Kumar et al., 2018). 


\section{Results}

The ITS2 sequences from putative Trichogramma samples varied in length between 409 and $600 \mathrm{bp}$. BLASTN searches of GenBank revealed that all of the obtained sequences showed similarities with ITS2-rDNAs of Trichogramma species with maximum identity scores ranging between 79 and $100 \%$. For most sequences, the parameter E-value of the BLASTN, which represents the number of hits that are expected to occur by chance when searching a database, was very low (i.e. equal or near to zero) indicating that the alignments were significant (Pertsemlidis and Fondon III, 2001). In this manner, it was possible to confirm the identities of all samples as determined previously using the morphological-based key.

Multiple sequence alignment revealed the existence of highly conserved regions in ITS2 sequences from the studied species, although some regions varied with respect to a single base. The multiple sequence alignment were obtained 599 sites between $T$. pretiosum, T. galloi, T. marandobai and T. manicobai, some 477 were considered conserved representing $>79 \%$ similarity between the four species. Out of the 122 variable sites, 21 (i.e. 3.5\% of the total sites) involved a single base substitution, as exemplified by the situation in T. pretiosum. These variable sites allowed the accessions belonging to each species to be distinguished one from another. In this context, it is of interest to note that $T$. galloi presented the smallest number of variable sites in comparison with the other species, containing only 14 variable sites.

According to the genetic distance matrix for the ITS2 region of rDNA (Table 2), the closest species were T. manicobai and T. marandobai (genetic distance of 0.015), whereas $T$. galloi and T. pretiosum were the most divergent (genetic distance of 0.086). The ITS2-rDNA sequence data of T. manicobai has been submitted for the first time to GenBank (accession no. MK226148).

Examination of the neighbor-joining dendrogram (Figure 1) revealed the presence of three clusters with group I being formed by accessions of T. manicobai and T. marandobai, group II comprising representatives of T. galloi and group III containing specimens of T. pretiosum. Allocation of all samples of T. manicobai and T. marandobai to group I demonstrates the genetic similarity between these two species. Interestingly, accessions of T. pretiosum were assigned to the same group irrespective of insect host

Table 2. Pair wise genetic distance matrix for Trichogramma species based on multiple sequence alignment of ITS2-rDNA sequences and determined using the maximum likelihood estimation method

\begin{tabular}{ccccc}
\hline Species & T. marandobai & T. pretiosum & T. galloi & T. manicobai \\
\hline T.marandobai & 0.000 & & & \\
T.pretiosum & 0.064 & 0.000 & & \\
T.galloi & 0.077 & 0.086 & 0.000 & 0.000 \\
T. manicobai & 0.015 & 0.064 & 0.083 & \\
\hline
\end{tabular}

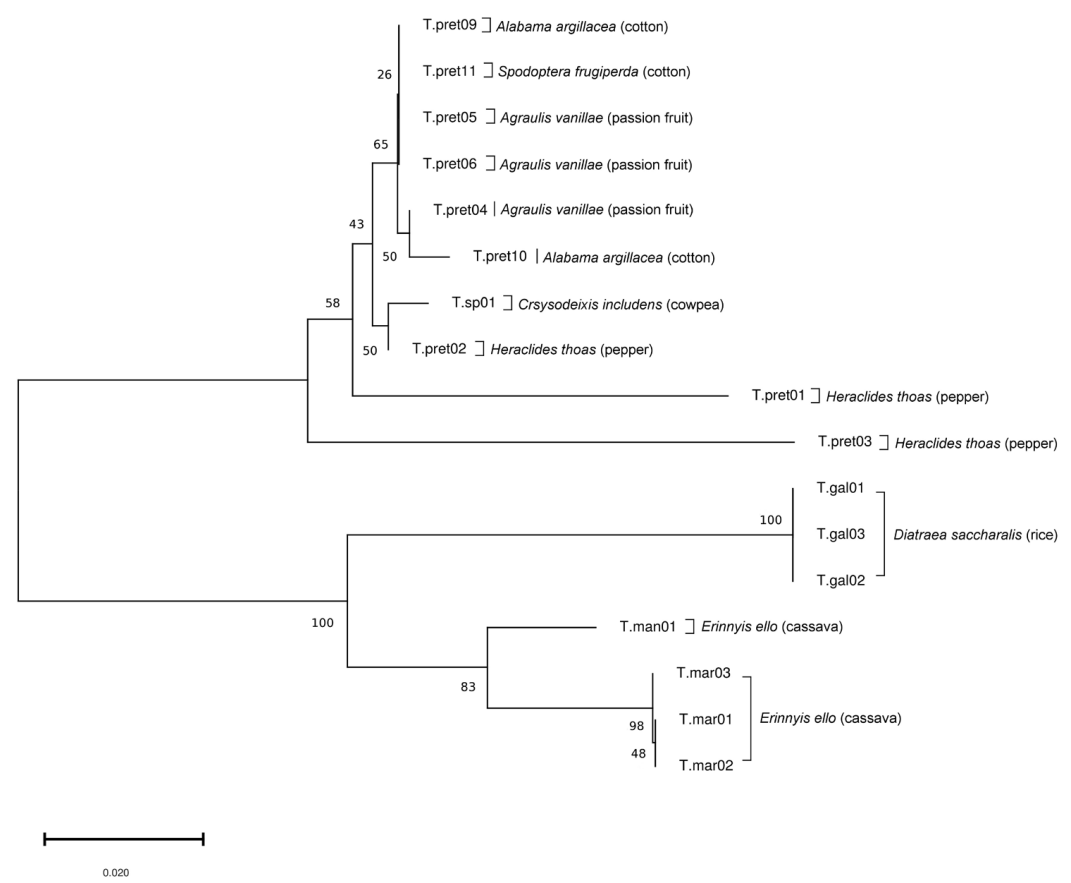

Figure 1. Neighbor-joining dendrogram based on the ITS2-rDNA barcode showing genetic relationships between the species Trichogramma studied (see Table 1 for sample description). Numbers on the branches are bootstrap values (\%) obtained from 1000 replicate analyses, while the bar below the dendrogram represents genetic distance. 
or plant species at the point of collection. Nevertheless, accessions labeled T.pret0 1 and T.pret03 were located distant from the other members of the group including the specimen T.preto02, which originated from the same pest host and plant species as the other two accessions.

\section{Discussion}

The ITS1 and ITS2 regions of rDNA have been proposed as standard DNA barcodes for diverse taxonomic groups by virtue of their extensive conservation during evolution (Vieira et al., 2014, 2015). Moreover, regarding the genus Trichogramma, these molecular markers are considered appropriate for identifying species that present intraspecific variations.

In the present work, the accessions of $T$. pretiosum presented intraspecific variations in ITS2-rDNA sequences produced by mutation events leading to single nucleotide substitutions. Such variations, termed single nucleotide polymorphisms (SNPs), occur in at least $1 \%$ of the population and are responsible for most of the genetic variations observed in individuals of a population (Brookes, 1999), such polymorphisms justify the topology of the dendrogram, where the accessions labeled T.pret01 and T.pret03 were observed located distant from the other members of the group, including the specimen T.preto02, which originated from the same host of pests and plant species that the two other accesses.

It is noteworthy that, among members of the Trichogramma, the species T. pretiosum is the most widely distributed and most polyphagous. In addition, T. pretiosum is a generalist parasitoid with a wide range of lepidopteran hosts including Nymphalidae (Agraulis vanillae), Noctuidae (Alabama argillacea and Spodoptera frugiperda) and Papilionidae (Heraclides thoas) (Zucchi et al., 2010). This capacity to thrive within diverse hosts justifies the large intraspecific genetic variation featured in the ITS2-rDNA barcode dendrogram (Figure 1). It should be noted, however, that the ITS2 region of rDNA lies between the nuclear rRNA genes $5.8 \mathrm{~S}$ and $28 \mathrm{~S}$ and, since it does not correspond to a protein coding region, it is not expressed as an observable trait (phenotype). For this reason, the genetic variations observed in accessions of $T$. pretiosum species were not related to the respective hosts.

In contrast to the above, T. marandobai and T. manicobai parasitize exclusively the eggs of Erinnyis ello (Sphingidae), a moth that is considered an important pest of cassava (Manihot esculenta) cultures in Brazil (Vieira et al., 2014). The limited host range exhibited by these two species is reflected in their genetic similarity regarding the ITS2 region and their allocation to the same group in the barcode dendrogram. Moreover, genetic similarity was observed between specimens of T. marandobai collected in Belém (Pará) and Rio Largo (Alagoas), locations that are some $1600 \mathrm{~km}$ apart, indicating that there is little genetic variability within this species.

Regarding T. galloi, the species showed considerable genetic homogeneity with respect to ITS2 sequences and the smallest number of variable sites. This finding is in agreement with the study of Querino and Zucchi (2004), who reported only minor intraspecific morphometric variations in T. galloi, with overlapping of accessions from Brazil and Uruguay and minimal differences between parasitoids from these two countries and specimens from Bolivia. The modest intraspecific variation in $T$. galloi is associated with a narrow host range, which comprises predominantly Diatraea saccharalis Fabricius, 1994 (Lepidoptera: Crambidae) in Brazil, where the parasitoid is considered to be a specialist species.

\section{Conclusions}

The ITS2 region meets the criteria for a suitable barcode in that it comprises a short nucleotide sequence and is highly reliable for DNA amplification and sequencing. The identification of Trichogramma species through ITS2 rDNA markers is useful and can be used to complement classifications based on morphological characters. The intraspecific variations in ITS2 rDNA detected in T. pretiosum are compatible with the generalist nature of the species and its capability of adapting to multiple hosts. In contrast, the specialist species T. manicobai and T. marandobai presented significant similarities between sites in the ITS2 region reflecting their adaptation to the same host (E. ello). No intraspecific genetic variability was detected in $T$. marandobai even between samples from widely separated geographical origins. Furthermore, based on the ITS2 sequences, it is possible to state that organisms of the species $T$. galloi have high genetic similarity, which is associated with a narrow range of hosts. Our study has demonstrated the potential of the ITS2 barcode for rapid identification of Trichogramma species, thus contributing to the effective application of these parasitoids in IPM programs and to studies on the evolution of pathogen-host interactions and conservation of parasitoid reservoirs.

\section{References}

ALTSCHUL, S.F., GISH, W., MILLER, W., MYERS, E.W. and LIPMAN, D.J., 1990. Basic local alignment search tool. Journal of Molecular Biology, vol. 215, no. 3, pp. 403-410. http://dx.doi. org/10.1016/S0022-2836(05)80360-2. PMid:2231712.

BROOKES, A.J., 1999. The essence of SNPs. Gene, vol. 234, no. 2, pp. 177-186. http://dx.doi.org/10.1016/S0378-1119(99)00219-X. PMid:10395891

JOHNSON, M., ZARETSKAYA, I., RAYTSELIS, Y., MEREZHUK, Y., MCGINNIS, S. and MADDEN, T.L., 2008. NCBI BLAST: a better web interface. Nucleic Acids Research, vol. 36, pp. W5-9. http://dx.doi.org/10.1093/nar/gkn201. PMid:18440982.

KUMAR, S., STECHER, G., LI, M., KNYAZ, C. and TAMURA, K., 2018. MEGA X: Molecular Evolutionary Genetics Analysis across computing platforms. Molecular Biology and Evolution, vol. 35, no. 6, pp. 1547-1549. http://dx.doi.org/10.1093/molbev/ msy096. PMid:29722887. 
LA SALLE, J. and GAULD, I.D., 1993. Hymenoptera and biodiversity. London: $\mathrm{CAB}$ International.

NAGARKATTI, S. and NAGARAJA, H., 1977. Biosystematics of Trichogramma and Trichogrammatoidea species. Annual Review of Entomology, vol. 22, no. 1, pp. 157-176. http://dx.doi. org/10.1146/annurev.en.22.010177.001105.

PERTSEMLIDIS, A. and FONDON III, J.W., 2001. Having a BLAST with bioinformatics (and avoiding BLASTphemy). Genome Biology, vol. 2, no. 10, pp. S2002. http://dx.doi.org/10.1186/gb2001-2-10-reviews2002. PMid:11597340.

PINTO, J.D., 2006. A review of the New World genera of Trichogrammatidae (Hymenoptera). Journal of Hymenoptera Research, vol. 15, pp. 38-163.

PINTO, J.D., VELTEN, R.K., PLATNER, G.R. and OATMAN, E.R., 1989. Phenotypic plasticity and taxonomic character in Trichogramma (Hymenoptera: trichogrammatidae). Annals of the Entomological Society of America, vol. 82, no. 4, pp. 414-425. http://dx.doi.org/10.1093/aesa/82.4.414.

QUERINO, R.B. and ZUCCHI, R.A., 2002. Intraspecific variation in Trichogramma bruni Nagaraja, 1983 (Hymenoptera: Trichogrammatidae) associated with different hosts. Brazilian Journal of Biology $=$ Revista Brasileira de Biologia, vol. 62, no. 4A, pp. 665-679. http://dx.doi.org/10.1590/S1519-69842002000400015. PMid:12659017.

QUERINO, R.B. and ZUCCHI, R.A., 2004. Análise morfométrica em espécies de Trichogramma (Hymenoptera: trichogrammatidae). Neotropical Entomology, vol. 33, no. 5, pp. 583-588. http://dx.doi. org/10.1590/S1519-566X2004000500007.

QUERINO, R.B. and ZUCCHI, R.A., 2005. An illustrated key to the species of Trichogramma (Hymenoptera: Trichogrammatidae) of Brazil. Zootaxa, vol. 1073, no. 1, pp. 37-60. http://dx.doi. org/10.11646/zootaxa.1073.1.3.

QUERINO, R.B. and ZUCCHI, R.A., 2012 [viewed 23 December 2019]. Guia de identificação de Trichogramma para o Brasil [online]. 2. ed. Brasília: Embrapa Informação Tecnológica. Available from: https://ainfo.cnptia.embrapa.br/digital/bitstream/ item/143227/1/Trichogramma-FINAL.pdf
QUERINO, R.B., MORAES, R.C.B.D. and ZUCCHI, R.A., 2002. Relative warp analysis to study morphological variations in the genital capsule of Trichogramma pretiosum Riley (Hymenoptera: trichogrammatidae). Neotropical Entomology, vol. 31, no. 2, pp. 217-224. http://dx.doi.org/10.1590/S1519-566X2002000200007.

QUERINO, R.B., ZUCCHI, R.A. and PINTO, J.D., 2010. Systematics of the Trichogrammatidae (Hymenoptera: Chalcidoidea) with a focus on the genera attacking Lepidoptera. In: F.L. CONSOLI, J.R.P. PARRA and R.A. ZUCCHI, eds. Egg parasitoids in agroecosystems with emphasis on Trichogramma. Dordrecht: Springer. Progress in Biological Control, no. 9.

STOUTHAMER, R., HU, J., VAN KAN, F.J.P.M., PLATNER, G.R. and PINTO, J.D., 1999. The utility of internally transcribed spacer $2 \mathrm{DNa}$ sequences of the nuclear ribosomal gene for distinguishing sibling species of Trichogramma. BioControl, vol. 43, no. 4, pp. 421-440. http://dx.doi.org/10.1023/A:1009937108715.

VAN OOSTERHOUT, C., VAN HEUVEN, M.K. and BRAKEFIELD, P.M., 2004. On the neutrality of molecular genetic markers: pedigree analysis of genetic variation in fragmented populations. Molecular Ecology, vol. 13, no. 5, pp. 1025-1034. http://dx.doi. org/10.1111/j.1365-294X.2004.02114.x. PMid:15078441.

VIEIRA, J.M., QUERINO, R.B. and ZUCCHI, R.A., 2014. On the identity of Trichogramma demoraesi Nagaraja (Hymenoptera: Trichogrammatidae), with a checklist and a key to Trichogramma species associated with Erinnyis ello (L.) (Lepidoptera, Sphingidae) in Brazil. Zootaxa, vol. 3869, no. 1, pp. 83-89. http://dx.doi. org/10.11646/zootaxa.3869.1.8. PMid:25283901.

VIEIRA, J.M., QUERINO, R.B., CÔNSOLI, F.L. and ZUCCHI, R.A., 2015. An integrative taxonomic approach to characterize Trichogramma marandobai (Hymenoptera: trichogrammatidae). Zootaxa, vol. 4021, no. 3, pp. 447-458. http://dx.doi.org/10.11646/ zootaxa.4021.3.4. PMid:26624141.

ZUCCHI, R.A., QUERINO, R.B. and MONTEIRO, R.C. (2010) Diversity and hosts of Trichogramma in the New World, with emphasis in South America. In: F.L. CONSOLI, J.R.P. PARRA and R.A. ZUCCHI, eds. Egg parasitoids in agroecosystems with emphasis on Trichogramma. Dordrecht: Springer. Progress in Biological Control, no. 9. 